\title{
COMPARATIVE MORPHOLOGICAL CHANGES IN SMOOTH MYOCYTES AND MACROFAGES CD16 IN PULMONARY ARTERY AND AORTA IN FETUSES AND NEWBORNS EXPOSED TO CHRONIC INTRAUTERINE HYPOXIA
}

\author{
Sorokina I., Markovsky V., Kaluzhyna O., Pliten O., Hol'yeva N. \\ Kharkiv National Medical University, Ukraine \\ https://doi.org/10.35339/ic.6.4.243-247
}

\begin{abstract}
Background. Oxygen deficiency, both acute and chronic, causes a variety of pathological changes in a number of organs and systems of fetuses and newborns. In particular, there are morphological changes in the vessels. Information in the available literature regarding the morphological state of smooth myocytes (SM) and cells expressing CD16 in the pulmonary artery (PA) and aorta of fetuses and newborns under such conditions of pregnancy is various and insufficient. Subjects and methods. The results of complex pathomorphological research of SM and macrophages CD16 of fetuses and newborns PA and aorta in chronic intrauterine hypoxia with the use of histological (staining with hematoxylin and eosin), immunohistochemical (MCA to Anti-Human Smooth Muscle Actin and MCA to CD16), morphometric, statistical methods are presented in the article. The investigation was performed on WAG line rats, observing all ethical norms and rules of handling of laboratory animals. The location of SM and macrophages CD16 in the wall of the PA and aorta in normal pregnancy and under oxygen deficiency, the density of their location in the field of vision (SM $-\times 1000, \mathrm{CD} 16-\times 600$ ) was calculated. A comparative analysis of the morphological characteristics of the studied cells between mentioned vessels was also carried out. Results. The macroscopic examination of the wall of PA and aorta in the group of fetuses and newborns from mothers with physiological pregnancy with a magnifier $(\times 3,8$ diopters $)$ revealed that it was elastic, had a smooth ivorish intima. Smooth muscle cells in PA and aorta during immunohistochemical identification are determined in intima and media, as well as in the adventitial vessels of vessels. With hypoxic effect their number decreased in comparison with control group, and the number of macrophages - increased in both described vessels. Conclusions. The density of smooth myocytes (SM) location in the thickness of the wall of PA and aorta in the fetuses and newborns during the physiological course of pregnancy differs significantly from each other with dominance in the first vessel. Under the influence of experimental chronic intrauterine hypoxia in PA and aorta of fetuses and newborns a significant $(\mathrm{p}<0.05)$ decrease in the density of smooth muscle cells location in the field of vision compared to control group without a significant difference between the studied vessels can be observed, as well as the tendency to increase the macrophages number, which expresses the marker CD16. The latter fact can be regarded as an increase in the macrophage reaction under the described conditions. Key words: aorta, CD16 cells, chronic intrauterine hypoxia, experiment, pulmonary artery, smooth myocytes.
\end{abstract}

\section{Introduction}

According to the WHO, cardiovascular pathology is the first among the causes of death of our planet population [1]. It is a long-known fact that mother's health and the course of

Corresponding Author:

Oksana Kaluzhyna - PhD,

Assistant of Department of pathological anatomy of Kharkiv National Medical University, Ukraine, e-mail: kaluzhina24@ukr.net pregnancy affect the fetus development [2]. A marked negative effect of oxygen deficiency on posterity during pregnancy, which is manifested especially in the second and third trimesters has been reported [3, 4]. Morphological studies devoted to the effects of chronic intrauterine hypoxia (CIH) on the state of the heart [5], the pituitary gland, the hematoencephalic barrier [6], the liver [7], the adrenal glands [8], the organs of the urinary system [9] of fetuses and newborns have been performed. The state of pulmonary 
artery (PA) and aorta has been investigated under conditions of acute postnatal hypoxia [10].

There are different points of view regarding the morphological changes of smooth myocytes (SM) under the oxygen insufficiency influence. Sjundjukova E.G. and others, (2013), Zamechnik T.V. and Rogova L.N. (2012) have noted their proliferative activity decrease in this state [11, 12]. At the same time, other authors have demonstrated PASM multiplying with insufficient oxygenation [13-15]. It should be also marked that severe oxygen deficiency and anoxia are the causes of proliferative activity decrease of smooth muscle cells in a given vessel [16-18].

The lack of a single point of view on the effect of intrauterine hypoxia influence on SM PA and aorta of fetuses and newborns, as well as the limited information in the available literature about the morphological features of CD16 macrophages in these blood vessels, determine our research relevance.

\section{Purposes, subjects and methods:}

2.1. Purpose of the study was to determine the difference in the morphological changes in the population of smooth myocytes (SM) and CD16 macrophages in the pulmonary artery (PA) and aorta in fetuses and newborns exposed to chronic intrauterine hypoxia $(\mathrm{CIH})$, based on a complex pathomorphological investigation.

\subsection{Subjects \& Methods}

This research was carried out within the research work of Pathological Anatomy Department of KhNMU: "Pathomorphological peculiarities of the fetus and the newborn formation under the influence of the mother's pathology" (state registration number 0110U001805, 2010-2014) and "Influence of maternal and fetal infection on embryogenesis and fetogenesis of progenies (clinical morphological study)" (state registration number 0115U000987, 2015-2019).

Pregnant female rats of the WAG line were subjected to altitude effects of hypoxia (7.500 m above sea level) from the pregnancy registration time and until the delivery for 20 minutes every day at the same time. Pregnant females (19-21 days of gestation) and females after giving birth were deduced from the experiment by intravenous injection of 2-2.5\% solution of sodium thiopental (7-10 mg per $1 \mathrm{~kg}$ of body weight), and then subjected to decapitation. Newborn rats 24 hours after birth 2-3 minutes were inhaled with $80 \%$ $\mathrm{CO} 2$ concentration under the cap, followed by decapitation.

The pathomorphological material was divided into control group (C) - fetuses and newborns from mothers with physiological pregnancy, and the study group $(\mathrm{CIH})$ - the fetuses and newborns who were exposed to HIC. The first group had 18 cases ( 7 fetuses, 11 newborns), the group of CIH had 16 cases (6 fetuses, 10 newborns).

All manipulations with animals and their withdrawal from the experiment were done in accordance with the requirements of the normative documents (European Convention for the Protection of Vertebrate Animals (Strasbourg, 18.03.1986), Council of the European Economic Community for the Protection of Vertebrate Animals (Strasbourg, 24.11.1986. ), the Law of Ukraine "On Medicinal Products", 1996, Articles 7, 8, 12, Guidelines of the CCI GSP (2008), GLR (2002), in accordance with the requirements and norms, the standard provisions on the ethics of the MoH of Ukraine No. 690 dated September 23, 2009).

PA and aorta were studied macroscopically (elasticity of the wall, color and intima status) using magnifier $(\times 3$, 8 diopters). After that, one piece from the vessel wall in the supravalvular region, was cut, fixed in $10 \%$ neutral formalin solution to standard paraffin processing of tissue for conducting a morphological examination. Serial sections of $4-5 \times 10^{-6} \mathrm{~m}$ thickness have been made from the prepared blocks on the Microtome cryostat MK-25. Histologic and morphometric studies were performed on Olympus BX-41 microscope (Japan) using Olympus DP-Soft (Version 3: 1), Microsoft Excel 2010 and the luminescence microscope Axiskop 40 (FS) (Carl Zeiss, Germany). The methods of the study were histological (staining with hematoxylin and eosin), immunohistochemical, morphometric, statistical. Morphometric parameters of PA, aorta (density of the SM location in the vessel wall in the field of vision $(\times 1000)$, the number of cells expressing CD16 receptors in the field of vision $(\times 600))$ were described under microscopic examination. Immunohistochemical studies were performed according to the indirect Coons method in the Brosman M. (1979) modification (to determine the location of macrophages in the vessel wall with MCA to CD16 (Novocastra Laboratories Ltd, UK.) and the indirect streptavidin-peroxidase method using MCA to Anti-Numan Smooth Muscle Actin ("DAKO", Denmark) (for typing smooth muscle cells). Indicators of markers expression, both quantitative and qualitative, were investigated in 8-10 randomly selected fields of vision of the microscope of histological sections at of $\times 600$ and $\times 1000$ magnification. The statistics were processed on a personal computer using 
the IBM SPSS Statistics (IBM Corp.) and Portable Statistica 8.0 (Statsoft, Inc) licensed software packages. Methods of variational, alternative and correlation analysis were used. Statistical significance of the differences in the comparable characteristics was evaluated by calculating the Student's t-criterion for groups with a normal distribution of the sign. Non-parametric U-test Mann-Whitney was used for small selections. Differences were considered statistically significant at a significance level of $\mathrm{p}<0.05$, which corresponds to $95 \%$ probability of sure prognosis.

\section{Conflict of interests}

There is no conflict of interests.

\section{Results and discussion}

The macroscopic examination of the wall of PA and aorta in the group of fetuses and newborns from mothers with physiological pregnancy with magnifier ( $\times 3,8$ diopters) revealed that it was elastic, had a smooth ivorish intima. Microscopically with hematoxylin and eosin staining, all three layers of the vessel were detected: internal, medium and external. SM had elongated star shape and were determined by MCA to Monoclonal Anti-Human Smooth Muscle Actin staining with moderate intensity expression marker in the cytoplasm. They were located in tunica intima, tunica media, and tunica adventitia, mostly in the vessels of the vessels. The density of these cells location in the thickness of the PA wall was $28.20 \pm 0.63$ cells in the field of vision $(\times 1000)$, and in aorta $-24.62 \pm 0.76$ cells in the field of vision $(\times 1000)$. These figures differed significantly from each other, probably due to the peculiarity of the blood flow of the fetus and the newborn in the early post-birth period [19]. Macrophages were identified using the CD16 marker, their number in the vascular wall of PA was $26.35 \pm 1.42$ cells in the field of vision $(\times 600)$, and in aorta $-26.00 \pm 1.36$ cells in the field of vision $(\times 600)$.

Consequently, the morphological state of the wall of PA and aorta in the fetuses and newborns of the control group corresponded to the generally accepted notion of the physiological norm [20].

The wall of PA and aorta in the group of fetuses and newborns under the $\mathrm{CIH}$ influence in a macroscopic study using magnifier $(\times 3$, 8 diopters) was elastic with smooth, whitish-gray intima. In microscopic study, all three vessel layers were determined in hematoxylin and eosin staining: tunica intima, media and adventitia.

In this group, the smooth muscle cells in both vessels were also elongated, with moderate intensity expression of brown color marker in the cytoplasm in immunohistochemical staining. They were present mostly in intima and medium, as well as in the adventitial vessels walls. The density of the SM location in PA in the field of vision $(\times 1000)$ was $20.00 \pm 0.35$ cells, these values were lower than the control ones (table). Similar changes in the density of investigated cells location were observed in aorta $-18.67 \pm 0.56$ cells in the field of vison $(\times 1000)$, which is lower than the control group.

Investigation of the number of macrophages in the PA wall using the CD16 marker revealed $29.45 \pm 0.84$ cells in the field of vision $(\times 600)$, and in aorta $-28.45 \pm 0.68$ cells in the field of vision $(\times 600)$. As it can be seen, their number in conditions of hypoxic effect increased.

As it is shown in table, the amount of SM in $\mathrm{PA}$ is bigger than in aorta during normal pregnancy $(p<0.05)$, while in groups with hypoxia, their number in investigated vessels is significantly decreased $(p<0.05)$ without significant difference between PA and aorta $(\mathrm{p} \geq 0.05)$. Our data are confirmed by a few literary reports, which inform about SM proliferation decrease in PA with severe oxygen deficiency, anoxia [17]. In this case, studies about SM peculiarities in vessels under acute hypoxia have different results. Some investigators report an increase in their proliferation [21] directly in the PA [15], while others report a decrease in the reproduction of these cells in the PA under such conditions [18].

The density of the smooth myocytes (SM) and cells expressing the marker CD16 location in the wall of pulmonary artery (PA) and aorta in the fetus and newborns

\begin{tabular}{|c|c|c|c|c|}
\hline \multirow{2}{*}{} & \multicolumn{2}{|c|}{$\begin{array}{r}\text { The density of the SM location } \\
\text { in the field of vision }(\times 1000)\end{array}$} & \multicolumn{2}{c|}{$\begin{array}{r}\text { Density of cells expressing the marker CD16 location } \\
\text { in the field of vision }(\times 600)\end{array}$} \\
\cline { 2 - 5 } & PA & Aorta & PA & Aorta \\
\hline C & $28.20 \pm 0.63$ & $\begin{array}{c}24.62 \pm 0.76 \\
p_{2}<0.05\end{array}$ & $26.35 \pm 1.42$ & $\begin{array}{r}26.00 \pm 1.36 \\
p_{2} \geq 0.05\end{array}$ \\
\hline CIH & $\begin{array}{c}20.00 \pm 0.35 \\
p_{1}<0.05\end{array}$ & $\begin{array}{c}18.67 \pm 0.56 \\
p_{1}<0.05 ; p_{2} \geq 0.05\end{array}$ & $\begin{array}{c}29.45 \pm 0.84 \\
p_{1} \geq 0.05\end{array}$ & $\begin{array}{c}28.45 \pm 0,68 \\
p_{1} \geq 0,05 ; p_{2} \geq 0.05\end{array}$ \\
\hline
\end{tabular}

Note. $\mathrm{p}_{1}$ is the veracity of the difference of two averages between the control and studied groups; $\mathrm{P}_{2}$ is the veracity of the difference of two averages between PA and aorta in one group. 
Study of the quantitative characteristics of macrophages expressing the CD16 marker in the examined vessels wall under the chronic hypoxia influence has tended to increase the density of their placement in both vessels compared with the control ( $p \geq 0.05)$, without differences between them ( $\mathrm{p} \geq 0.05)$.

These indications may evidence that macrophage reaction occurs when exposed to the $\mathrm{CIH}$. This fact is confirmed in the literature about the presence of the described cells in hypoxic regions, including inflammatory and tumor processes [22-24].

\section{Conclusions}

1. Density of placement of SM in the field of vision $(\times 1000)$ in the thickness of the walls of PA and aorta in the fetuses and newborns during the physiological course of pregnancy significantly differs from each other with domination in the first vessel (PA - 28.20 \pm 0.63 cells, aorta $24.62 \pm 0.76$ cells).

2. Under the influence of experimental $\mathrm{CIH}$ in PA and aorta in fetuses and newborns, there is a significant $(p<0.05)$ decrease in the density of smooth muscle cells location in the field of vision compared with control, but without significant difference between the examined vessels $(\mathrm{p} \geq 0,05)$.

3. Fetal chronic oxygen deficiency is manifested in the tendency to increase the number of macrophages expressing the CD16 marker in the wall of PA and aorta in the fetuses and newborns as compared with the control parameters ( $\mathrm{p} \geq 0.05)$.

\section{Reference}

1. Cardiovascular-diseases-(cvds). Retrieved from https://www.who.int/ru/news-room/fact-sheets/ detail/cardiovascular-diseases-(cvds).

2. Banerjee, B. (2009). Information, Education, and Communication Services in MCH Care Provided at an Urban Health Center. Indian J Community Med., 34 (4), 298-300. doi: 10.4103/0970-0218.58386.

3. Hutter, D., Kingdom, J., Jaeggi, E. (2010). Causes and Mechanisms of Intrauterine Hypoxia and Its Impact on the Fetal Cardiovascular System: A Review. International Journal of Pediatrics, 9. Article ID 401323. doi:10.1155/2010/401323.

4. Herrera, EA., Camm, EJ., Cross, CM., Mullender, JL., Wooding, FB., Giussani, DA. (2012). Morphological and functional alterations in the aorta of the chronically hypoxic fetal rat. Journal of vascular research, 49, 50-58.

5. Mekenbaeva, R.T. (2013). Klinicheskie i morfologicheskie izmenenija v miokarde u umershih novorozhdennyh, perenesshih perinatal'nuju gipoksiju [Clinical and morphological changes in the myocardium in dead newborns after perinatal hypoxia]. Clinical medicine of Kazakhstan, 3 (29), 11-15.

6. Kyhtenko, O.V. (2018) Patologichna anatomija gemato-encefalichnogo bar'jeru pry gipoksychnomu stresi v perynatal'nomu periodi [Pathological anatomy of the hematoencephalic barrier with hypoxic stress in the perinatal period]. Avteref. dys. na zdobuttja nauk. stupenja kand. med. nauk, Kharkiv National Medical University, Kharkiv.

7. Markovskij, V.D., Sakal, A.A. (2016). Vlijanie hronicheskoj vnutriutrobnoj gipoksii na morfofunkcional'noe sostojanie pecheni potomstva krys [Influence of chronic intrauterine hypoxia on morphofunctional liver state of rats progeny]. Visnyk problem biologii' i medycyny, 2 (129), 200-204.

8. Tovazhnjanskaja, V.D., Jakovcova, I.I., Sorokina, I.V. (2015). Morfo-funkcional'nye osobennosti kory nadpochechnikov plodov krysy pri vozdejstvii hronicheskoj vnutriutrobnoj gipoksii [Morphological and functional features of the adrenal cortex of rat fetuses when exposed to chronic intrauterine hypoxia]. Aktual'ni pytannja suchasnoi' medycyny. Visnyk UMSA, 3 (2), 123-131.

9. Miroshnichenko, M.S., Markovskij, V.D., Sorokina, I.V. (2013). Vlijanie hronicheskoj vnutriutrobnoj gipoksii na morfofunkcional'nye osobennosti organov mochevydelitel'noj sistemy plodov i novorozhdennyh [The influence of chronic intrauterine hypoxia on the morphofunctional features of the urinary system organs of fetuses and newborns]. Morfologija, VII (2), 57-60.

10. Markovskij, V.D., Zvereva, I.S. (2017). Morfologicheskie osobennosti aorty i legochnoj arterii u novorozhdennyh, perenesshih ostruju postnatal'nuju gipoksiju v jeksperimente [Morphological features of the aorta and pulmonary artery in newborns who had acute postnatal hypoxia in an experiment]. Morphologia, 11 (1), 33-36.

11.Sjundjukova, E.G., Medvedev, B.I., Sashenkov, S.L., Jakovleva, Ju.A., Kanajkina, A.Ju., Chernyh, S.L., Safronenkova, I.A. (2013). Struktura akusherskoj patologii u beremennyh s prejeklampsiej [The structure of obstetric pathology in pregnant women with preeclampsia]. Vestnik JuUrGU. Serija "Obrazovanie, zdravoohranenie, fizicheskaja kul'tura", 13 (1), 90-95. 
12. Zamechnik, T.V., Rogova, L.N. (2012). Gipoksija kak puskovoj faktor razvitija jendotelial'noj disfunkcii i vospalenija sosudistoj stenki (obzor literatury) [Hypoxia as a trigger factor for the development of endothelial dysfunction and inflammation of the vascular wall (literature review)]. Vestnik novyh medicinskih tehnologij, 19 (2), 393-394.

13. Venckivs'kyj, B.M., Zaporozhan, V.M., Senchuk, A.Ja. (2002). Gestozy vagitnyh: Navchal'nyj posibnyk [Preeclampsia of pregnants : Textbook]. Kyiv: Aconit.

14. Zelinskij, A.A., Karaush, E.A. (2005) Perinatal'nye poteri i faktory riska akusherkoginekologicheskoj patologii [Perinatal loss and obstetric-gynecological pathology risk factors]. Zbirnyk naukovyh prac' Asociacii' akusheriv-ginekologiv Ukrai'ny, pp. 183-187.

15. Preston, IR., Hill, NS., Warburton, RR., Fanburg, BL. (2006). The role of 12-lipoxygenase in hypoxia-induced rat pulmonary artery smooth muscle cell proliferation. The American Journal of Physiology Lung Cellular and Molecular Physiology, 290, L367-L374.

16. Bilousov, O.G. (2006) Prognozuvannja, rannja diagnostyka ta profilaktyka tjazhkyh form preeklampsii' [Forecasting, early diagnosis and prevention of severe forms of preeclampsia]. Dys. na zdobuttja nauk. stupenja kand. med. nauk, Donec'kyj derzhavnyj medychnyj universytet im. M. Gor'kogo, Donec'k.

17. Eddahibi, S., Fabre, V., Boni, C., Martres, M.P., Raffestin, B., Hamon, M., Adnot S. (1999). Induction of serotonin transporter by hypoxia in pulmonary vascular smooth muscle cells relationship with the mitogenic action of serotonin. Circulation Research, 84, 329-336.

18. Stiebellehner, L., Frid, MG., Reeves, JT., Low, RB., Gnanasekharan, M., Stenmark, KR. (2003). Bovine distal pulmonary arterial media is composed of a uniform population of well-differentiated smooth muscle cells with low proliferative capabilities. American Journal of Physiology - Lung Cellular and Molecular Physiology, 285, L825-L828.

19. Murphy, P.J. (2005). The fetal circulation. Continuing education in anaesthesia, 5(4), 107-112.

20. Bacakova, L., Travnickova, M., Filova, E., Matejka, R., Stepanovska, J., Musilkova, J., Zarubova, J., Molitor, M. (2018). The Role of Vascular Smooth Muscle Cells in the Physiology and Pathophysiology of Blood Vessels. In K. Sakuma, Muscle Cell and Tissue - Current Status of Research Field (230-257). Location: Intech Open. http://dx.doi.org/10.5772/intechopen.77115.

21. Wu, JH., Goswami, R., Kim, LK., Miller, WE., Peppel, K., Freedman, NJ. (2005). Heterogenic G proteins and platelet-derived growth factor receptor - contribute to hypoxic proliferation of smooth muscle cells. American Journal of Respiratory Cell and Molecular Biology, 33, 412-419.

22. Lewis, C., Murdoch, C. (2005). Macrophage Responses to Hypoxia. Implications for Tumor Progression and Anti-Cancer Therapies. The American Journal of Pathology, 167(3), 627-635. doi: 10.1016/S0002-9440(10)62038-X.

23. Burke, B., Giannoudis, A., Corke, KP., Gil,l D., Wells, M., Ziegler-Heitbrock, L., Lewis, CE. 2003. Hypoxia-Induced Gene Expression in Human Macrophages. Implications for Ischemic Tissues and Hypoxia-Regulated Gene Therapy. The American Journal of Pathology, 4, 1233-1243.

24. Tazzyman, S., Murdoch, C., Yeomans, J., Harrison, J., Muthana, M. (2014). Macrophage-mediated response to hypoxia in disease. Hypoxia (Auckl), 2, 185-196. doi: 10.2147/HP.S49717.

Received: 28-Jun-2019

Accepted: 13-Dec-2019 